\title{
Observations of snowpack ripening in the Sierra Nevada, California, U.S.A.
}

\author{
Richard Kattelmann, ${ }^{1}$ Jeff Dozier ${ }^{2}$ \\ ${ }^{1}$ Sierra Nevada Aquatic Research Laboratory, University of California, Star Route 1, Box 198, Mammoth Lakes, California 93546, U.S.A. \\ ${ }^{2}$ School of Environmental Science and Management, University of California, Santa Barbara, California 93106, U.S.A.
}

\begin{abstract}
The transition from a dry, sub-freezing snow cover to isothermal snow freely conducting water was observed near timberline in the Sierra Nevada, California, U.S.A. Although there were few major stratigraphic boundaries in the snowpacks observed, minor textural discontinuities were sufficient to both route water laterally downslope and later create ice layers at these strata. During the first few days of snowmelt, downslope movement of water parallel to the strata allowed water to bypass lower layers of the snow cover on slopes and converge in microtopographic depressions on level terrain, creating isolated drains through the snowpack. In addition to these drains, flow fingers associated with holes in the ice sheets delivered water to the base of the snow several days prior to the thorough wetting of the snow pack. Formation of a series of ice lenses just below the snow surface every night released much more latent heat than did ice-layer development within the bulk of the snowpack or at its base.
\end{abstract}

\section{INTRODUCTION}

In most seasonally snow-covered areas, a transition occurs between a winter accumulation season and a spring melt season. During this transition period, the character of snow cover changes and sustained snowmelt runoff begins. Increased energy input to the snow surface and consequent availability of meltwater initiate these changes. As liquid water enters the snowpack, processes collectively known as ripening, aging or melt metamorphism ensue (e.g. Colbeck, 1977). These processes include grain growth and rounding, icelayer formation, warming of the snow to the melting temperature, densification, capillary retention of liquid water and creation of a flow network. Complex feedback mechanisms between these processes influence their rates and spatial variability.

The onset of snow runoff in different years may vary over a 2 month period, complicating reservoir management and creating conflicts among water users. The U.S. Office of Technology Assessment (U.S. Congress, 1983) and World Meteorological Organization (1986) recommended improvements in abilities to forecast timing of early spring runoff.

The early phases of snowmelt runoff release a large fraction of the snow cover's ionic load and thereby affect the impacts of acidic precipitation on aquatic ecosystems in snow-dominated regions. Since the pioneering studies of Johannessen and Henriksen (1978) and Colbeck (1981), many field and laboratory investigations have demonstrated that $50-90 \%$ of the solute load of the snowpack is removed by the first $20-30 \%$ of seasonal snowmelt runoff. The spatial distribution of this initial portion of snowmelt runoff around a drainage basin can control the concentration and duration of elevated solute loads in streams (Colbeck, 1981; Williams and Melack, 1989). Improved knowledge of factors influencing the onset of snowmelt runoff should help in studies of the spatial distribution of an ionic pulse.
In his review of water movement through snow, Colbeck (1978, p. 168) stated, "very little is known about the details of snow during the transient period between the dry, fresh snow and the mature, ripe snow". Comprehensive studies of snowpack ripening (Marsh, 1983, 1987a, b, 1988, 1991; Marsh and Woo, 1984a, b, 1985) in the Canadian High Arctic provided much insight into processes occurring during the ripening of cold snow cover at high latitudes. Ripening processes in Greenland were well described by Pfeffer and Humphrey (1996). In situ measurements of temperature and heat flux within snow packs illustrated patterns of heat transfer during the infiltration of liquid water in sub-freezing snow (Sturm and Holmgren, 1993; Conway and Benedict, 1994; Pfeffer and Humphrey, 1996). Several researchers examined various aspects of snowpack ripening in the Sierra Nevada and Cascades, U.S.A. (e.g. Church, 1940; Church, 1941; Gerdel, 1945, 1948, 1954; U.S. Army Corps of Engineers, 1956; Sulahria, 1972; Smith, 1974; Kattelmann, 1986; McGurk and Kattelmann, 1986). However, these studies have not provided a complete description of the transition from winter conditions to spring snow that is releasing meltwater. More information about formation of ice layers and flow networks is needed to improve the effectiveness of water-routing and chemical-release models of snow (Colbeck, 1991).

Some applications of physically based snowpack models assume horizontal homogeneity (e.g. Jordan, 1991). Descriptions of snow pack processes and properties should contribute to more realistic assumptions for modeling. This paper discusses observations of water movement into and through initially dry snow and the formation of ice layers and flow channels within snowpacks of the Sierra Nevada, California. This project is considered a case-study because ripening processes are highly variable from year to year and from location to location (Colbeck, 1991), but the observations reported here support many of the findings of Pfeffer and 
Humphrey (1996) in a different snow climate. As additional field studies of this nature are conducted in a variety of settings, some consistent patterns of snowpack evolution may emerge that will allow improved modeling capability.

\section{REVIEW OF RIPENING PROCESSES}

After water is generated at (or just below) the snow surface by melting, or is added by rainfall, the $0^{\circ} \mathrm{C}$ liquid first contacts $0^{\circ} \mathrm{C}$ snow grains. These grains achieve a more rounded shape and the larger grains grow in size as the smaller grains lose mass to them (Wakahama, 1968; Colbeck, 1973; Marsh, 1987b). When liquid water is contiguous around the grains (occurring when it occupies more than about $7 \%$ of the total volume), individual grain growth and separation are particularly rapid (Colbeck, 1982). At lower water contents where liquid-water inclusions are not contiguous, grains grow more slowly but become bonded together in clusters. When the water freezes, large polycrystalline grains form. These different types of metamorphism may occur simultaneously only a few $\mathrm{mm}$ apart. The resulting differences in grain-size and configuration combined with pre-existing variations in microscale snowpack structure (e.g. wind crusts, different crystals, buried surface hoar, irregular microtopography) lead to a non-uniform distribution of liquid water, which enhances differences in rates of metamorphism and consequent grain-size (Colbeck, 1978).

Where the snow is at $0^{\circ} \mathrm{C}$, liquid water will be retained by capillary pressure in the pore spaces. This capillary requirement, or irreducible water content, will vary at the grain scale depending on the size and shape of the pore spaces. More water will be held in the smaller pores of fine-grain snow than in the larger voids of coarse-grain snow. Where fine-grain snow overlies coarse-grain snow, water will accumulate in the upper layer until the pressure difference between the layers is relieved when water can flow into the lower layer (Wankiewicz, 1979). If there is a sufficient discontinuity in snow texture, water will accumulate in a saturated layer until water pressure at the interface approaches atmospheric pressure (the extreme case where there is only void space). Where water pressure is equal across the interface, water will begin to flow into the lower layer under the influence of gravity. The thickness of such saturated layers can reach 20-30 mm (Colbeck, 1975; Wankiewicz, 1976). If the saturated layer is inclined, water will tend to flow downslope. Thickness of saturated layers increases downslope as water accumulates from expansion of the contributing area. At some point downslope, water will cross the impeding layer because of either a local increase in permeability at the layer boundary or equalization of water pressure above and capillary pressure below. These zones where water traverses a snow layer are often called flow fingers and have analogues in other porous media (e.g. Glass and others, 1989; Ritsema and others, 1993). These channels become preferred pathways for additional flow as grain-size and permeability increase within them (Colbeck, 1978). In theory, flow fingers should become better developed in warmer snowpacks, where low temperatures do not inhibit their formation (Marsh and Woo, 1984a). Creation of saturated layers and flow fingers contributes to an irregular distribution of liquid water at a scale 2-4 orders of magnitude greater than the grain scale.

At high altitudes and latitudes, subsurface snow is typic- ally many degrees below $0^{\circ} \mathrm{C}$ at the beginning of spring melt. Liquid water percolating below the surface freezes when encountering cold ice grains, which then warm from release of latent heat as thermal equilibrium is approached. However, the quantity of water that can be frozen within the snowpack is small. Less than $20 \mathrm{~mm}$ of water was frozen in snowpacks up to $1.2 \mathrm{~m}$ deep in the High Arctic (Marsh and Woo, 1984a). About $90 \%$ of this water froze into distinct ice layers. Additional freezing of liquid water occurs as accretion on isolated grains (Pfeffer and others, 1990). A basal ice layer may form at the snow/soil interface if the soil is below $0^{\circ} \mathrm{C}$ and has limited permeability (Woo and Heron, 1981). Formation of ice layers within the snow pack depends on formation of flow fingers. Flow fingers are required to transport water through cold snow until it reaches a textural discontinuity deeper in the snowpack where it spreads out and freezes. The ice layers, in turn, allow water to pass through them in a few places, generating a point release of water to the underlying layer (Marsh and Woo, 1984a). Ice layers formed during the dry-to-wet transition period continue to strongly influence water movement through the snowpack later in spring (Furbish, 1988; Colbeck, 1991).

\section{STUDY AREA AND METHODS}

This project was conducted during two spring seasons at two locations in the Sierra Nevada. A pilot study was made in 1988 at Emerald Lake in Sequoia National Park $\left(36^{\circ} 35^{\prime} \mathrm{N}\right.$, $118^{\circ} 40^{\prime} \mathrm{W}$ ), at $2950-3100 \mathrm{~m}$ a.s.l. We observed snow properties in snow pits at four sites on north aspects with different energy-balance characteristics related to shading by the local terrain. The 1988 snow season had less than normal snowfall, with most of the snowpack in place by mid-January and only one additional storm at the end of February. The water equivalence of the snowpack at the upper sites was about $1 \mathrm{~m}$ at the beginning of surface melt in late March.

More field observations were made in 1991 on and around Mammoth Mountain $\left(37^{\circ} 37^{\prime} \mathrm{N}, 119^{\circ} 02^{\prime} \mathrm{W}\right)$, southeast of Yosemite National Park at about $2900 \mathrm{~m}$ a.s.l. Six sites were monitored intensively throughout the transition period: three on level ground (referred to as A-C), one with a south aspect (site $\mathrm{S}$ ), one with a southeast aspect (site $\mathrm{SE}$ ) and one in a forest meadow at $2400 \mathrm{~m}$ a.s.l (site M). Five other sites were monitored occasionally. A meteorological station including snowmelt lysimeters and in situ snowpack-temperature sensors was adjacent to sites A-C. Because of failure of the radiation recorder during the study period, adequate estimates of daily snowmelt from energybalance calculations could not be made.

Most of the 1991 snowpack formed during March when $>4 \mathrm{~m}$ of snow fell on Mammoth Mountain. Peak snow water equivalence was $0.6-0.8 \mathrm{~m}$ at most sites. Skies were clear on only a couple of days during March, so there was little development of surface crusts, and storm layers were difficult to distinguish except on south-facing slopes. All Mammoth Mountain sites except site $\mathrm{M}$ were subject to strong winds, which resulted in uneven deposition and redistribution of snow. Skies were mostly clear from 28 March through 9 April, as is typical of spring weather in the eastern Sierra Nevada. However, the rest of April was characterized by cloudy afternoons, below-average temperatures and occasional snowfall, conditions that limited snowmelt and prolonged the transition period. 
At the six principal sites, snow properties were observed every day except during and immediately after snowfall. Monitoring began on 27 March and continued through 7 May at the slower-melting sites. Basic snow characteristics, such as stratigraphy, density, temperature and liquid-water content, were observed in more than 140 snow pits. In the first 10 days, snow pits with little penetration of liquid water were excavated to a depth of only $1 \mathrm{~m}$. The pits were partially refilled after observation, and $0.5-1 \mathrm{~m}$ of undisturbed snow was removed from the south or southwest wall for each new observation. This successive cutting-back of the pit wall was assumed to be adequate to avoid lateral influences of the exposed face, such as energy input and ice formation, but this procedure introduced concerns about spatial variation. The snow observed on successive days was considered to be similar to, but not identical with, the snow exposed previously. The destructive sampling procedure creates some uncertainty in the results, though presumably not enough to alter the basic findings. The pits did not appear to influence the structure or microtopography of the snow cover where the subsequent sampling occurred.

In each snow pit, replicate measurements were made in two profiles 1-2 $\mathrm{m}$ apart. Standard observations included stratigraphic descriptions, temperature at $0.1 \mathrm{~m}$ intervals, density in $0.1 \mathrm{~m}$ increments with a $1 \mathrm{~L}$ sampler, and liquidwater content. The latter was measured in the early morning to observe residual water storage after overnight drainage, using a capacitance probe (Denoth, 1989). Five to ten liquidwater measurements were obtained in arbitrary $20 \mathrm{~cm}$ thick increments with the probe oriented vertically on its edge. In stratigraphic descriptions, the term lens was used if a horizontal feature was discontinuous, and layer was used if the feature was continuous across the $1-2 \mathrm{~m}$ wide pit face. Sequential excavation of the pit face in shallow slices allowed examination of the continuity of features. Dye was applied with a hand sprayer to the snow surface during the first few days to observe movement of water with respect to the layer structure. Dye concentrations, amounts and application rates $(1-2 \mathrm{~mm}$ of water in about $15 \mathrm{~min}$ ) were believed to be small enough to avoid alteration of qualitative flow properties. The dye observations were conducted several meters away from the areas of routine snow-pit observation.

\section{RESULTS}

\section{Characteristics of the winter snow cover}

Before the onset of surface melt in 1988, the snowpack at the upper sites at Emerald Lake was 2.3-2.7 $\mathrm{m}$ deep and had one obvious discontinuity at $1.7-1.9 \mathrm{~m}$ above the ground, apparently the exposed surface from mid-January to late February. Surface crusts were unlikely to develop on the north-facing slopes during the inter-storm periods of December and early January because of low Sun angle. Densities were progressively larger at greater depth: $250 \mathrm{~kg} \mathrm{~m}^{-3}$ near the surface to $450 \mathrm{~kg} \mathrm{~m}^{-3}$ near the ground. At a site receiving several hours of sunlight each day, temperatures increased from $-4{ }^{\circ} \mathrm{C}$ near the surface to $-1^{\circ} \mathrm{C}$ at the ground before melting began. At a site receiving minimal direct sunlight before mid-April, the temperature of the top meter was $-10^{\circ}$ to $-8^{\circ} \mathrm{C}$ at the onset of melt.

At Mammoth Mountain in 1991, buried surface crusts were found in snow pits at the two south-facing sites ( $\mathrm{S}$ and $\mathrm{SE}$ ), although they were poorly developed compared to the one at Emerald Lake. At the other sites, the storm layers of March were generally indistinguishable from each other. Dye applied to the surface did not penetrate $>0.5 \mathrm{~m}$ at any site and was generally not found below $0.3 \mathrm{~m}$ from the surface. Up to 16 discrete layers in this near-surface zone transmitted dyed water applied several meters upslope, but they could not be identified in dry snow even in backlit sections. Snow from December and early January was obvious at the base of profiles at sites that had shallow snow cover before the March storms. Snow depths at the end of March were $2-3 \mathrm{~m}$ at most of the sites. Depth at the start of the observation period at the low-elevation site $(\mathbf{M})$ was $1.5 \mathrm{~m}$, and $3.8 \mathrm{~m}$ of snow were found at a north-facing site. Initial densities were $<200 \mathrm{~kg} \mathrm{~m}^{-3}$ near the surface and $>400 \mathrm{~kg} \mathrm{~m}^{-3}$ near the base. Prior to melt, snowpack temperatures were as low as $-10^{\circ} \mathrm{C}$ near the surface, but were $-2^{\circ}$ to $0^{\circ} \mathrm{C}$ at the base. These temperature profiles were inverted compared to those observed in the Canadian High Arctic where permafrost underlies the snow cover (Marsh and Woo, 1984a, figs 3 and 7), but are typical of the Sierra Nevada (McGurk, 1983). Soil temperatures at the study sites are generally near $0^{\circ} \mathrm{C}$ by the onset of melt, but the soil could remain frozen if autumn temperatures were unusually low and snow cover did not begin to insulate the soil until late November or December. Thus, there is the potential for basal ice layers to form in these areas of the Sierra Nevada, although we have not observed layers $>3 \mathrm{~cm}$ thick.

\section{Densification}

At Mammoth Mountain, snow pack densities increased very quickly during the first few days after the cessation of snowfall on 27 March and before substantial surface melting. For example, mean density changed from 280 to $330 \mathrm{~kg} \mathrm{~m}^{-3}$ between 27 March and 2 April and from 260 to $340 \mathrm{~kg} \mathrm{~m}^{-3}$ between 27 March and 3 April at two sites on level ground, and from 300 to $380 \mathrm{~kg} \mathrm{~m}^{-3}$ between 30 March and 3 April at site SE. Changes were greatest close to the surface. After this initial period, average densities increased almost linearly throughout the period. Introduction of liquid water was not associated with any obvious changes in the rate of densification averaged throughout the snowpack. Densities of $0.1 \mathrm{~m}$ increments varied too much between samples to lead to any conclusions about trends in a particular layer. At Emerald Lake, mean densities were already about $400 \mathrm{~kg} \mathrm{~m}^{-3}$ at the start of observations and increased only slowly through April.

\section{Temperature}

Snow temperatures at Emerald Lake ranged from $-1^{\circ}$ to $-3^{\circ} \mathrm{C}$ until liquid water percolated into successively deeper layers, warming the snow pack to $0^{\circ} \mathrm{C}$ within $2-4$ days at the start of April.

At Mammoth Mountain, temperature profiles were initially below $-5^{\circ} \mathrm{C}$ between $1 \mathrm{~m}$ and the surface (Fig. 1). These temperatures increased rapidly during the sunny days following the last snowfall of March. At the southeastfacing site (SE), the snowpack became isothermal in 4 days (Fig. la). At the sites on level terrain, temperatures warmed to between $-3^{\circ}$ and $-1^{\circ} \mathrm{C}$ within 7 days (Fig. $1 \mathrm{~b}$ and $\mathrm{c}$ ), but remained slightly below $0^{\circ} \mathrm{C}$ in much of the profile throughout April. In situ temperature sensors in the lowest $0.5 \mathrm{~m}$ of the snowpack near the level sites did not attain $0^{\circ} \mathrm{C}$ until 5 and 6 May. 

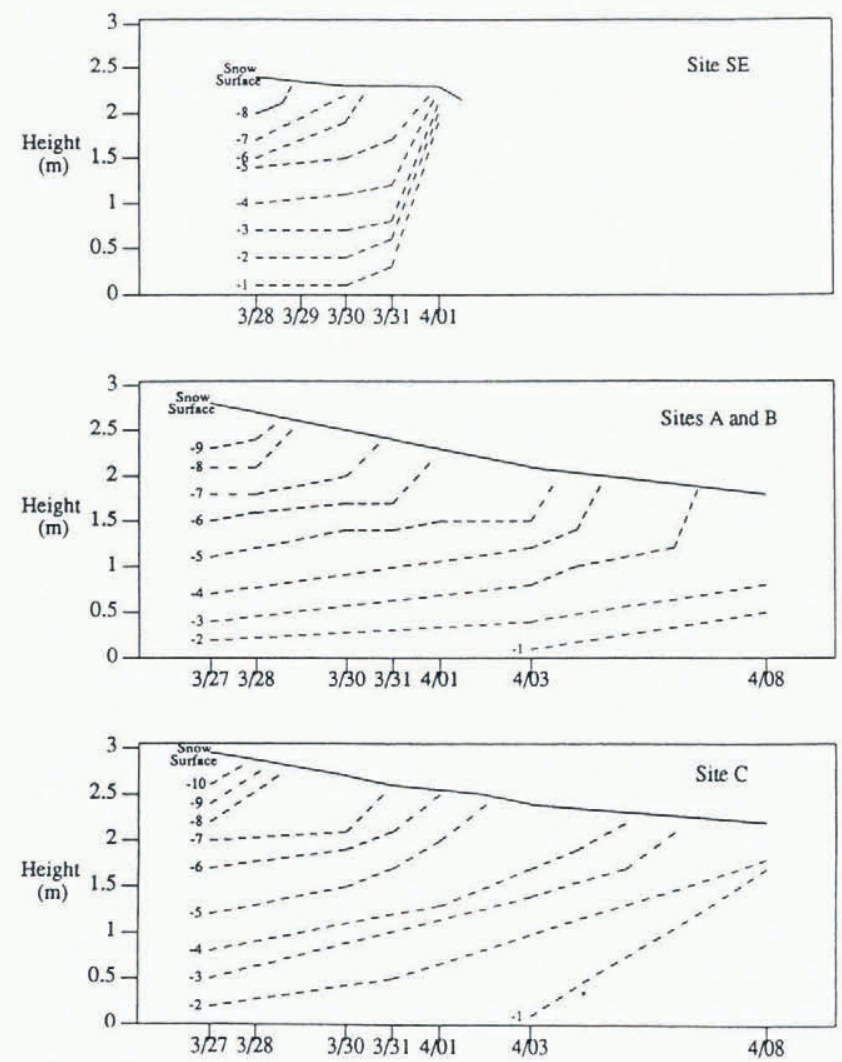

Fig. 1. Snowpack temperatures warmed rapidly before the introduction of liquid water. Site SE was on a southeast-facing slope and warmed much faster than sites $A-C$, which were on level ground. All four sites were on Mammoth Mountain.

\section{Liquid-water content}

When liquid water was first visible on the snow surface at Emerald Lake, some areas in the upper snowpack were found to contain $0.5-1 \%$ liquid water by volume with the capacitance probe, even though most of the snow had not yet warmed to $0^{\circ} \mathrm{C}$ (Kattelmann, 1990b). Liquid water was observed visually in isolated flow fingers up to $1 \mathrm{~cm}$ in diameter and on some layer interfaces, while the temperature of snow a few $\mathrm{cm}$ away was $-1^{\circ}$ to $-3^{\circ} \mathrm{C}$. For the first week after the snowpack became isothermal, almost all measurements were $0.5-3.0 \%$ by volume, with a few higher values of up to $6 \%$. As more water flowed through the snowpack, average values for layers were generally $1-3 \%$.Values within the same layer were rarely consistent between the 5-10 measurements. Usually, these differences were $<2 \%$ by volume, but in about one-quarter of the 140 layers sampled the minimum and maximum values within the same layer differed by at least $2 \%$ by volume. There were a few layers where the minimum value was $0.5-1 \%$ and the maximum value was $5-6 \%$.

At Mammoth Mountain, small amounts of liquid were found below the night-freeze crust at all sites except those with north aspect within a few days of the weather clearing in late March. Water content averaged over the entire profile increased from near zero to $>2 \%$ by volume over 10 day periods in early April on south-facing slopes, and in late April on level terrain (Fig. 2). Average water contents below the top $0.5 \mathrm{~m}$ of snow at the south-facing sites remained $<1 \%$ by volume and were mostly zero for the first 8 days of the 10 day wetting period. Linear and dendritic drainage patterns were noted on these slopes, indicating that water was flowing downslope. However, water appeared to remain

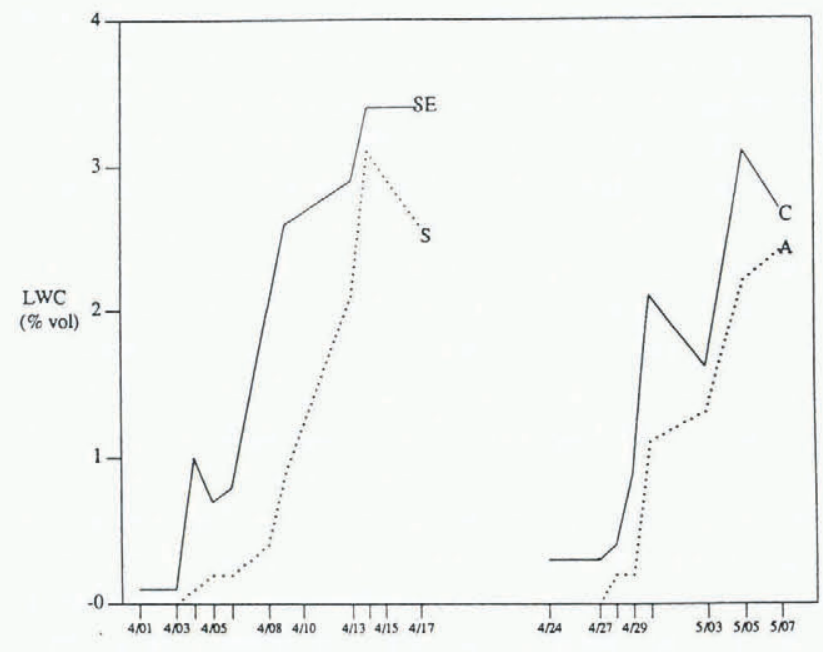

Fig. 2. Average liquid-water content ( $L W C$ ) increased over a 10 day period at the south-facing sites ( $S$ and $S E$ ) and the level sites ( $A$ and $C$ ) at Mammoth Mountain.

near the surface, as suggested by dye application and the absence of liquid water in pit profiles below $0.5 \mathrm{~m}$ from the surface. Icicles weighing several $\mathrm{kg}$ also formed each night at the top of the upslope pit walls where water flowed out of the near-surface layers. Icicles did not form on the lower part of the walls. By the 11th and 12th days (in different pits) of the study, or 5 and 6 days into the wetting period, average water content was $>2 \%$ at levels above $1 \mathrm{~m}$ in one pit and above $0.7 \mathrm{~m}$ in the other pit (Fig. 3). Liquid-water-content measurements of zero were still common in the lower part of these profiles, and a few zero or near-zero values were still noted
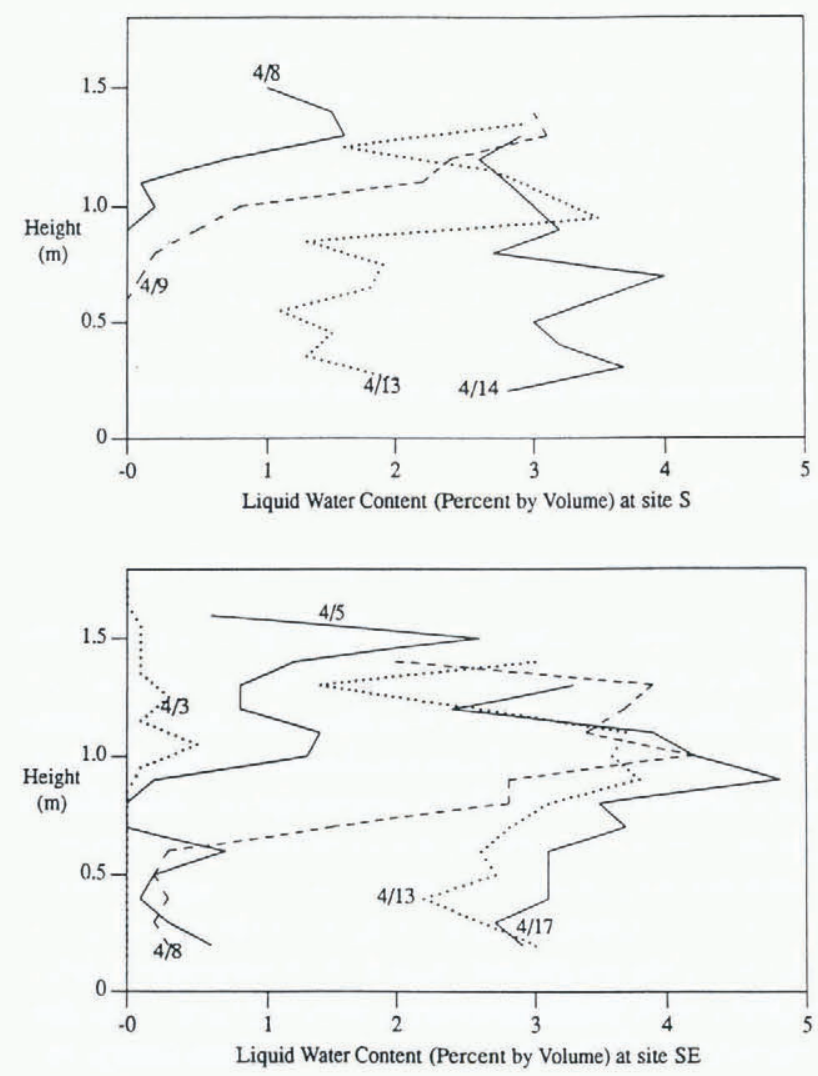

Fig. 3. Liquid-water content remained stratified (little water in the lower part) well into the wetting period on the south-facing slopes (sites $S$ and SE) at Mammoth Mountain. Each line represents the profile for liquid-water content for a particular day. 
in the upper wet zone. After 4 or 5 days, average water contents were $\geq 2 \%$ by volume throughout the profile, and all measurements revealed some liquid water.

At the level sites on Mammoth Mountain, liquid-water measurements were above zero only near the surface until late April. Water then penetrated to the base within 3 days at two of the sites, which had values consistently above $1 \%$ by volume thereafter (Fig. 4). At the third level site, where the pits crossed through a series of shallow depressions in the snow surface, water contents were $>1 \%$ throughout most of the profile, including the base, on 24 and 30 April when pits coincided with depressions. However, water did not reach the base of pits located outside of depressions at this site until 7 May. Dry zones were found in this area as late as 5 May. Water began to flow from the snowmelt lysimeters on 7 and 8 May.
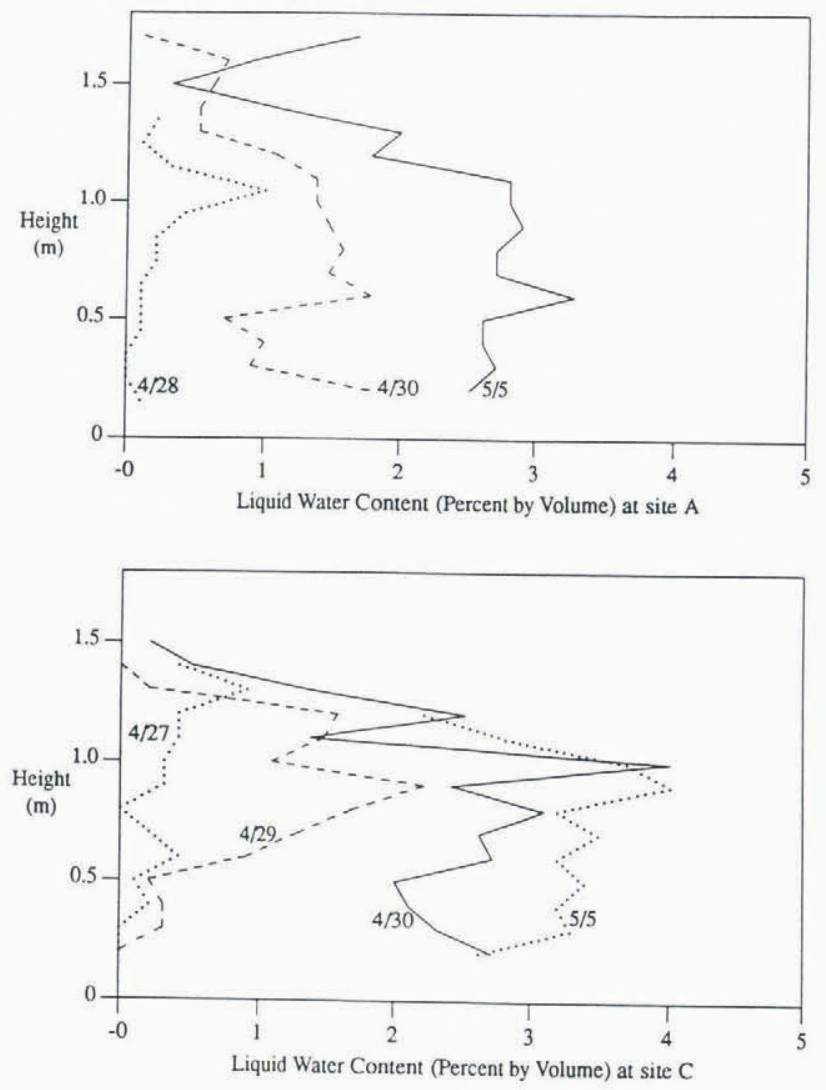

Fig. 4. On level terrain, water content increased slowly throughout the profile, possibly because of vertical routing through flow fingers. Each line represents the profile for liquid-water content for a particular day.

Liquid water was also observed at the base of a $2.8 \mathrm{~m}$ deep snow pit dug in a shallow depression near sites $\mathrm{A}-\mathrm{C}$ on 6 April. Water contents averaging $1.5 \%$ by volume over the entire profile that included several dry zones were measured in another depression on $8 \mathrm{April}$. At the other extreme, water contents exceeding $5 \%$ by volume, with the probe inserted vertically, were found in only 43 measurements out of $>2800$. Only 12 of these high values exceeded $10 \%$ by volume, and all these measurements were at the low-elevation site (M).

\section{Stratigraphic features and ice formation}

At Emerald Lake, the main stratigraphic features noticed during the first days of observation were irregular wet zones a few $\mathrm{cm}$ across at their widest section in the upper $0.2-0.5 \mathrm{~m}$ of the snowpack. These wet zones were generally, though not always, oriented parallel to the strata of the snowpack. Water spreading along the newly exposed pit face sometimes masked their original shape. Thin ice layers and columns were subsequently found in the same part of the profile. Ice columns were later found deeper in a couple of profiles. Between 5 and 15 thin ice lenses were found in the top $0.2 \mathrm{~m}$ of almost all profiles. A $30-50 \mathrm{~mm}$ thick ice layer grew where an old crust was identified in three pits. In one of these pits, its formation progressed in 4 days from a thin $(1-2 \mathrm{~mm})$ ice layer to discontinuous wet zones to multiple thin ice lenses to the thicker ice layer. In another pit, this ice layer formed from a region of large grain clusters and thin lenses in 6 days.

At Mammoth Mountain, the first stratigraphic features were noticed 3 days after cessation of snowfall. These features included irregular wet zones and lenses, ice in thin lenses and small irregular chunks, and lenses of coarse grains. The irregular chunks of ice - features not long enough to be considered an ice column - were assumed to be the result of freezing of the small wet zones. As water percolated to greater depth, ice lenses 1-20 mm thick developed. These features ranged in length from about 0.05 to $0.5 \mathrm{~m}$ across the pit face. Truly continuous ice layers were not observed below the night-freeze crust in 1991. After 6 days at the south-facing site and 16-24 days at the level sites, lenses and layers of clusters and coarse-grain snow became prominent, usually above or surrounding ice lenses. These layers were sometimes obviously wet or even saturated. Appearance of coarse-grain layers coincided with local increases in liquid-water content (Figs 3 and 4). After the coarse-grain layers formed, ice lenses became less apparent.

The most active area of ice formation was in the uppermost $0.2 \mathrm{~m}$, where water was produced during the day and frozen at night. This zone was characterized by the presence of 5-20 ice lenses and layers, as well as coarse grains and clusters. Ice occurred both as layers $10-50 \mathrm{~mm}$ thick with little apparent internal stratification and as multiple thin layers each 1-10 $\mathrm{mm}$ thick laminated together or separated by equally thin layers of coarse grains with little interstitial ice. On clear days, this zone would become completely thawed, with a "rotten" texture and considerable void space. The depth of night freezing ranged from about 0.05 to $0.2 \mathrm{~m}$ during the study.

Few stratigraphic features were noted below $0.5 \mathrm{~m}$ above the ground. This part of the snow pack contained the oldest, warmest and densest snow. At the base of the snowpack, ice was found at two of the level sites by mid-April, and by early May at the third level site. Occasionally, liquid water was also found ponded on this basal ice layer or on the soil. The basal ice layer was generally $10-40 \mathrm{~mm}$ thick but was discontinuous.

\section{DISCUSSION}

The snow cover at Emerald Lake and Mammoth Mountain was highly variable in its properties and in its response to the introduction of liquid water. Total depth and position of stratigraphic features varied by tens of $\mathrm{cm}$ over distances of a few meters, causing some uncertainty in describing progression of layer development based on destructive sampling. Otherwise, the observed variability in snow prop- 
erties provided evidence of the importance of isolated channels in routing water through a newly wetted snowpack. Snow densities varied by tens of $\mathrm{kg} \mathrm{m}^{-3}$ over distances of a few $\mathrm{cm}$, and had the greatest discrepancies when liquid water was present in one sample but not the other. Temperatures at a given depth in the profile varied by up to $2^{\circ} \mathrm{C}$ as water entered that part of the snowpack. Liquid water was irregularly distributed as well, with dry zones adjacent to those with several per cent liquid water by volume. Although other causes of the increased variability in density and temperature coincident with introduction of liquid water can be imagined, a highly irregular distribution of liquid water as measured provides the most obvious explanation. Previous evidence of flow channels has relied on dye applications and excavations of "fossil" channels represented by ice columns (e.g. Ahlmann and Tveten, 1923; Gerdel, 1948, 1954; Marsh and Woo, 1984a; Marsh, 1988).

During the initial introduction of liquid water into the snowpacks observed at Emerald Lake and Mammoth Mountain, its highly irregular distribution makes the concept of a uniform wetting front inappropriate. Convergence of nearsurface flow in shallow depressions on level snow surfaces allowed water to reach the base of the snowpack as much as 1 month in advance of a general or background wetting front. Water may penetrate only a few $\mathrm{cm}$ below the surface before flowing laterally along discontinuities to points of convergence (Kattelmann, 1990a). Enough water can converge to allow penetration of the entire snowpack at even weak melt rates. On sloping terrain, water initially flowed only downslope parallel to the strata within the near-surface layers, completely bypassing the lower snowpack. Similar phenomena have been suggested by Marsh (quoted by Colbeck, 1991) and Pfeffer and Humphrey (1996). In the cases observed here, ice layers were not present, and merely a change in texture led to the non-vertical flow. If we overlook these more extreme situations, the time lag between arrival of water at the base in flow fingers and apparently thorough wetting of the snowpack down to its base was $3,6,9,15,17$ and 20 days at various sites on Mammoth Mountain. The two extremes (3 and 20 days) occurred at level sites that were $<100 \mathrm{~m}$ apart with otherwise similar characteristics.

Most of the ice formation occurred in the night-time freeze zone, producing each night a hard surface crust $0.1-$ $0.2 \mathrm{~m}$ thick composed of up to 20 thin ice lenses and layers. The nightly formation of these layers interrupted the supply of water to the bulk of the snowpack, and reduced melting on the following day by cooling below $0^{\circ} \mathrm{C}$ (Bengtsson, 1982). Development of ice layers occurred where water froze in about $20-30 \%$ of the volume of a particular layer, increasing the density of each layer by $200-300 \mathrm{~kg} \mathrm{~m}^{-3}$. For example, formation of ten ice layers of $5 \mathrm{~mm}$ thickness (including pre-existing snow grains) required the radiational loss of $3-5 \mathrm{MJ} \mathrm{m}^{-2}$ and would freeze $11-17 \mathrm{~mm}$ of water. The small amount of daily melt produced early in the spring could completely refreeze each night in this near-surface zone. Only when meltwater production exceeded several $\mathrm{mm} \mathrm{d}^{-1}$ could substantial amounts of water move deeper into the snow pack, in areas other than convergence zones.

Within the snowpack, a maximum of 10-20 thin ice lenses were found at most of the sites. As Marsh and Woo (1984a) pointed out, these discontinuous structures could not be associated with any visible pre-melt strata and probably form where water in flow fingers spreads out on some minor textural discontinuity. However, these features were more common than in the Arctic, and the cumulative release of latent heat from their formation accounted for the final warming of the snowpack. With 10-20 lenses in most profiles averaging $2 \mathrm{~mm}$ in thickness when ice lenses were observed to be at the maximum stage of development, $20-40 \mathrm{~mm}$ of ice lenses would be present if they were continuous. If density changed by $300-400 \mathrm{~kg} \mathrm{~m}^{-3}$ at the location of the lenses and they occupied one-quarter to one-half of the horizontal area, then $0.5-2.7 \mathrm{MJ} \mathrm{m}^{-2}$ of energy would be released by their formation and $2-9 \mathrm{~mm}$ of water would freeze. Snowpacks at average temperatures of $-2^{\circ}$ to $-1^{\circ} \mathrm{C}$, total depths of $1.5-2.0 \mathrm{~m}$ and average densities of $350-400 \mathrm{~kg} \mathrm{~m}^{-3}$ could freeze $3-10 \mathrm{~mm}$ of water equivalence or about the same as the observed amount of ice formed. Marsh and Woo (1984a) found that $8-18 \mathrm{~mm}$ of water froze in thick ice layers in the colder but shallower arctic snow cover. Between 30 and $40 \mathrm{~mm}$ of liquid water were present in the $1.3-1.5 \mathrm{~m}$ of snow after it was isothermal and lacked any dry zones. The equivalent average value of about $2 \%$ by volume is somewhat lower than commonly used estimates of irreducible water content of $7 \%$ of the pore volume (Colbeck, 1978) or $3 \%$ of the total volume (Colbeck and others, 1990). Considerably more water was stored by capillary retention than was frozen in these snow packs - a situation opposite the Arctic observations of Marsh and Woo (1984a). The snowpacks observed during this study formed during short parts of the snow-accumulation season and lacked the usually obvious stratigraphy that results from inter-storm periods of several days' duration. The one thick ice layer observed at Emerald Lake during this study formed at a distinct inter-storm boundary, as have dozens of others observed by the author over the years and described by Berg (1982).

Stratigraphy exposed on pit walls is a sample of horizontal strata extending laterally throughout the snowpack. The features observed are mere pieces of these more extensive structures. Sequential cutting-back of the pit wall in thin increments revealed some details of the horizontal form and extent of strata. The ice lenses documented in the pit profiles were usually parts of ice sheets containing many holessomething visualized as a slice of Swiss cheese embedded in a granular medium (Fig. 5). The holes of assorted sizes (0.1- $0.5 \mathrm{~m}$ across) constituted about $50-75 \%$ of the total
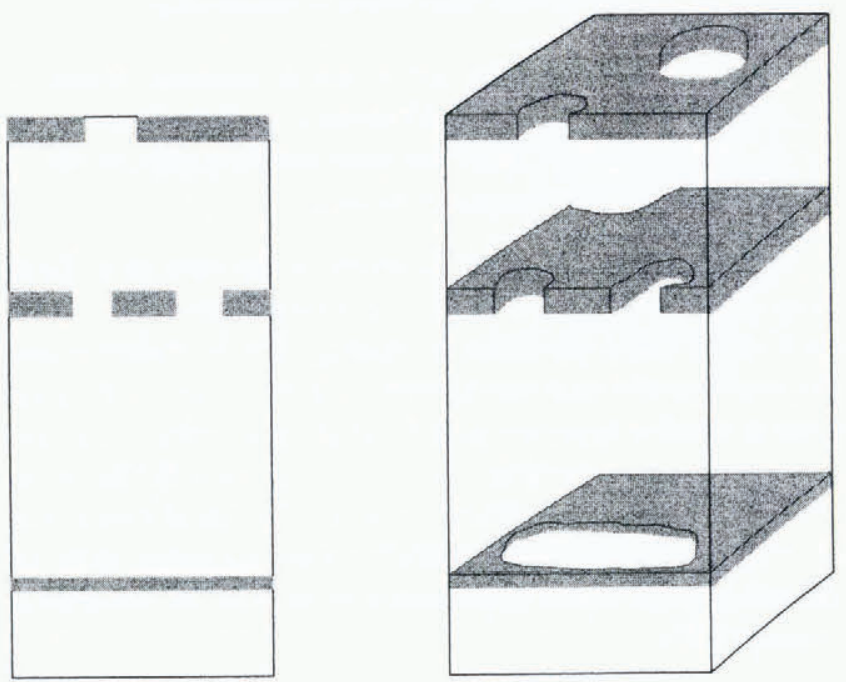

Fig. 5. Schematic diagram of apparently discontinuous ice lenses (gray bands) as typically observed in a stratigraphic profile of a snow pit (left), and portions of the corresponding three-dimensional ice layers containing holes (right). 
area of the feature. Marsh and Woo (1984a) characterized ice layers as two types: thicker, continuous and thinner, discontinuous. Our observations in the Sierra Nevada suggest there are two types of discontinuous ice formations: isolated, somewhat randomly located lenses not associated with any apparent strata, as described by Marsh and Woo (1984a), and the "Swiss cheese" variety forming at textural discontinuities. Such features may be incompletely developed ice layers that lacked sufficient water and cold content to become continuous. Holes in the "Swiss cheese" layers also provide a place for flow fingers to originate where water spills off the edge of the ice. These holes are an extreme version of the "lateral variations in the properties" of impeding horizons where Marsh and Woo (1984a) postulated flow-finger formation.

At Mammoth Mountain, ice lenses did not form until after the snowpack had already warmed up to $-2{ }^{\circ} \mathrm{C}$ or warmer. Apparently, the $-5^{\circ}$ to $-10^{\circ} \mathrm{C}$ snow present at the start of the study warmed by conduction and freezing of water in irregular forms before it had a chance to spread out laterally. Liquid-water content as measured did not increase until after ice-lens formation was complete. Within a few days of water availability, ice lenses readily degenerated into coarse-grain layers. Basal ice layers were much thinner than those in the Arctic because of warmer substrate. Nevertheless, a few cm of basal ice can form in the "warm" snowpacks of the Sierra Nevada and delay release of initial meltwater that has percolated through the snowpack in zones of convergent flow.

\section{IMPLICATIONS}

Results of this study may have applications in guiding future field research and eventual improvement of models of water and chemical release from snow cover. Observations of flowpath geometry and liquid-water distribution will be reported in a subsequent paper. As has been demonstrated many times before (e.g. Gerdel, 1954; Marsh and Woo, 1984a; Kattelmann, 1986; Conway and Benedict, 1994; Pfeffer and Humphrey, 1996), but incorporated into few models (Colbeck, 1979; Marsh and Woo, 1984b), water flows in distinct channels and is non-uniformly distributed. Lateral downslope flow along textural discontinuities may account for a greater fraction of total water movement than has been realized. The first pulse of water released from the snowpack probably comes from convergent flow at points of localized surface depression. Flow fingers can deliver water through the snowpack for weeks before the entire snowpack becomes wet. Even thin ice sheets perforated with holes can reorganize the flow field at many levels within the snow cover.

Removal of contaminants from the snowpack depends on where water is available to act as a transport medium. Solute concentration of outflow from an Arctic snowpack was greater in areas of low flow than in adjacent sections of the snowpack producing water at higher rates (Marsh and Pomeroy, 1993). Accumulation of water at layer boundaries allows ions deposited on the snow surface between storms to be mobilized at the very beginning of water release. However, deep layer boundaries within sloping snowpacks may be bypassed by the initial flush. Although the first 1-3\% of all meltwater released may have bypassed most of the snowpack, the rest of the snowpack appeared to be wetted to the base before $5 \%$ of the snowpack had melted. Quantifying these phenomena will continue to be difficult, but at least we must avoid the temptation to assume uniformity.

\section{ACKNOWLEDGEMENTS}

This work was supported by the California Air Resources Board and NASA's Earth Observing System program. We are grateful for the constructive comments of the reviewers and associate editor.

\section{REFERENCES}

Ahlmann, H.W:son and A. Tveten. 1923. The recrystallization of snow into firn and the glaciation of the latter. Geogr. Ann., 5(1), $52-58$.

Bengtsson, L. 1982. The importance of refreezing on the diurnal snowmelt cycle with applications to a northern Swedish catchment. Nord. Hydrol. $13(1), 1-12$.

Berg, N. H. 1982. Layer and crust development in a central Sierra Nevada snow pack: some preliminary observations. Proc. West. Snow Conf., 50th Annual Meeting, 19-23 April 1982, Reno, Nevada, 180-183.

Church, J. E. 1941. The melting of snow. In Central Snow Conference, December 11-12, 1941, Michigan State College, East Lansing, Proceedings. Vol. 1, 21-32.

Church, P. E. 1940. Ice-crusts and snow-settling at Snoqualmie Pass, season of 1939-40. Trans. Am. Geophys. Union, 21 IIIB), 928-931.

Colbeck, S. C. 1973. Theory of metamorphism of wet snow. CRREL Res. Rep. 313.

Colbeck, S. C. 1975. Grain and bond growth in wet snow. International Association of Hydrological Sciences Publication 114 (Symposium at Grindelwald 1974 - Snow Mechanics), 51 - 61 .

Colbeck, S. C. 1977. Short-term forecasting of water run-off from snow and ice. 7. Glaciol., 19 (81), 571-588.

Colbeck, S. C. 1978. The physical aspects of water flow through snow. $A d v$, Hydrosci., 11, $165-206$

Colbeck, S. C. 1979. Water flow through heterogeneous snow. Cold Reg. Sci. Technol., $1(1), 37-45$.

Colbeck, S. C. 1981. A simulation of the enrichment of atmospheric pollutants in snow cover runoff. Water Resour. Res., 17 (5), 1383- 1388.

Colbeck, S. C. 1982. An overview of seasonal snow metamorphism. Rer. Geophys. Space Phys., 20 (1), 45-61.

Colbeck, S. C. 1991. The layered character of snow covers. Rev. Geophys., 29 (1), $81-96$.

Colbeck, S. C. and 7 others. 1990. The international classification for seasonal snow on the ground. Wallingford, Oxon, International Association of Scientific Hydrology. International Commission on Snow and Ice.

Conway, H. and R. Benedict. 1994. Infiltration of water into snow. Water Resour. Res., 30 (3), 641-649.

Denoth, A. 1989. Snow dielectric measurements. Adv. Space Res., 9 (1), 233-243.

Furbish, D. J. 1988. The influence of ice layers on the travel time of meltwater through a snowpack. Arct. Alp. Res., 20 (3), 265-272.

Gerdel, R.W. 1945. The dynamics of liquid water in deep snowpacks. Trans. Am. Geophys. Union, 26 (1), 83-90.

Gerdel, R.W. 1948. Physical changes in snow-cover leading to runoff, especially to floods. International Association of Scientific Hydrology Publication 30 (General Assembly of Oslo 1948 - Snow and Ice), 42-54.

Gerdel, R. W. 1954. The transmission of water through snow. Trans. Am. Geophys. Union, 35 (3), 475-485.

Glass, R. J., T. S. Steehuis and J.-Y. Parlange. 1989. Wetting front instability. 1. Theoretical discussion and dimensional analysis. Water Resour. Res., 25, $1187-1194$.

Johannessen, M. and A. Henriksen. 1978. Chemistry of snow meltwater: changes in concentration during melting. Water Resour. Res., 14(4), 615-619.

Jordan, R. 1991. A one-dimensional temperature model for a snow cover: technical documentation for SNTHERM.89. CRREL Spec. Rep. 91-16.

Kattelmann, R. C. 1986. Measurements of snow layer water retention. In Kane, D. L., ed. Symposium: Cold Regions Hydrology, $22-25$ July 1986. Fairbanks, Alaska. Proceedings. Bethesda, MD, American Water Resources Association, 377-386. (AWRA Technical Publication Series TPS-86-1.)

Kattelmann, R. 1990a. Liquid water at the snowpack surface. EOS, 71 (43), 1328.

Kattelmann, R. C. 1990b. Variability of liquid water content in an alpine snow pack. In ISSW '90. A merging of theory and practice. International Snow Science Workshop, 9-13 October 1990, Bigfork, Montana. Proceedings. Bigfork. MT, ISSW'90 Committee, 261-265.

Marsh, P. 1983. Ripening processes and meltwater movement in Arctic snowpacks. (Ph.D. thesis, McMaster University.)

Marsh, P. 1987a. Factors limiting snowmelt runoff in a permafrost environ- 
ment. Proc. West. Snow Conf., 55th Annual Meeting, 14-16 April 1987, Vancouver, British Columbia, $61-68$.

Marsh, P. 1987b. Grain growth in a wet Arctic snow cover. Cold Reg. Sci. Technol., 14 (1), 23-31.

Marsh, P. 1988. Flow fingers and ice columns in a cold snowcover. Proc. West. Snow Conf., 56th Annual Meeting, 19-2l April 1988, Kalispell, Montana, $105-112$.

Marsh, P. 1991. Water flux in melting snow covers. In Corapcioglu, M.Y., ed. Advances in porous media. Vol. I. New York, Elsevier Science Publishers, 61-124.

Marsh, P. and J. W. Pomeroy. 1993. The impact of heterogeneous flow paths on snowmelt runoff chemistry. Proc. East. Snow Conf., 50th Annual Meeting, 8 - 10 June 1993, Québec, Que., 231- 238.

Marsh, P. and M.-K. Woo. 1984a. Wetting front advance and freezing of meltwater within a snow cover. 1. Observations in the Canadian Arctic. Water Resour. Res., 20 (12), 1853-1864.

Marsh, P. and M.-K. Woo. 1984b. Wetting front advance and freezing of meltwater within a snow cover. 2. A simulation model. Water Resour. Res., 20 (12), $1865-1874$.

Marsh, P. and M.-K. Woo. 1985. Meltwater movement in natural heterogeneous snow covers. Water Resour. Res., 21 (11), 1710-1716.

McGurk, B. J. 1983. Snow temperature profiles in the central Sierra Nevada. Proc. West. Snow Conf., 5lst Annual Meeting, 19-21 April 1983, Vancouver, Washington, 9-18.

McGurk, B. J. and R. C. Kattelmann. 1986. Water flow rates, porosity and permeability in snow packs in the central Sierra Nevada. In Kane, D. L., ed. Symposium: Cold Regions Hydrology, 22-25 July 1986, Fairbanks, Alaska. Proceedings. Bethesda, MD, American Water Resources Association, 359-366. (AWRA Technical Publication Series TPS-86-1.)

Pfeffer, W. T. and N. F. Humphrey. 1996. Determination of timing and location of water movement and ice-layer formation by temperature measurements in sub-freezing snow. J. Glaciol., 42 (141), 292304.

Pfeffer, W. T., T. H. Illangasekare and M. F. Meier. 1990. Analysis and modeling of melt-water refreezing in dry snow. 7. Glaciol., 36 (123), 238-246.

Ritsema, C. J., L. W. Dekker, J. M. H. Hendrickx and W. Hamminga. 1993. Preferential flow mechanism in a water repellent sandy soil. Water Resour.
Res., 29, 2183-2193.

Smith, J. L. 1974. Hydrology of warm snowpacks and their effects upon water delivery. In Santeford, H. S. and J. L. Smith, eds. Advanced concepts and techniques in the study of snow and ice resources. Washing ton, DC, National Academy of Sciences, 76-89.

Sturm, M. and J. Holmgren. 1993. Rain-induced water percolation in snow as detected using heat flux transducers. Water Resour. Res., 29 (7), 2323- 2334.

Sulahria, M. B. 1972. Prediction of water retention capacity of high elevation snow packs on the east side of the Sierra Nevada. (Ph.D. thesis, University of Nevada, Reno.

United States Army Corps of Engineers. 1956. Snow hydrology: summary report of the snow investigations. Portland, OR, U.S. Army Corps of Engineers. North Pacific Division.

United States Congress. 1983. Water-related technologies for sustainable agriculture in United States arid/semiarid lands. Washington, DC, United States Congress. Office of Technology Assessment. (OTA F-212.)

Wakahama, G. 1968. The metamorphism of wet snow. International Association of Scientific Hydrology Publication 79 (General Assembly of Bern 1967 Snow and Ice, $370-379$.

Wankiewicz, A. 1976. Water percolation within a deep snow pack - field investigations at a site on Mt. Seymour, British Columbia. (Ph.D. thesis, University of British Columbia.)

Wankiewicz, A. 1979. A review of water movement in snow. In Colbeck, S. C. and M. Ray, eds. Modeling of Snow Cover Runoff, 26-28 September 1978. Hanover, New Hampshire. Proceedings. Hanover, NH, U.S. Army Corps of Engineers. Cold Regions Research and Engineering Laboratory, $222-252$.

Williams, M. W. and J. M. Melack. 1989. Effects of spatial and temporal variation in snow melt on nitrate ion and sulfate ion pulses in melt waters within an alpine basin. Ann. Glaciol., 13, 285-288.

Woo, M. -K. and R. Heron. 1981. Occurrence of ice layers at the base of High Arctic snowpacks. Arct. Alp. Res., 13 (2), 225- 230.

World Meteorological Organization (WMO). 1986. Intercomparison of models of snowmelt runoff. Geneva, World Meteorological Organization. (WMO Publ. 646, OH-23.

MS received 1 April 1997 and accepted in revised form 29 fanuary 1999 